\title{
The study results of the filtration process in the ground dams body and its chemical effect on piezometers
}

\author{
Asror Yangiev $^{*}$, Galiya Omarova $^{2}$, Farida Yunusova ${ }^{1}$, Dilmurat Adjimuratov ${ }^{1}$, and Aliya \\ Risalieva $^{2}$ \\ ${ }^{1}$ Tashkent Institute of Irrigation and Agricultural Mechanization Engineers, Tashkent, Uzbekistan \\ ${ }^{2}$ Taraz regional university named after M.Kh.Dulaty, Taraz, Kazakhstan
}

\begin{abstract}
The article describes the definition of filtration flow gradients in the dam's body on the example of the Kattakurgan reservoir, the analysis of the reasons for their change in cross-section. Evaluation of the aggressiveness of the filtration flow in the dam's body plays an important role in ensuring the stability of the reservoir dam and its parts. To assess the aggressiveness of the filtration flow in the dam's body, it is necessary to know the action pattern of the filtration water in the reservoir dam and its effect on the elements of the dam. In addition, the chemical composition of the water in the piezometers was analyzed in the laboratory to determine the aggressive effect of sulfate elements on the piezometers and their corrosion. Measures on the observations of systemic piezometers were also mentioned.
\end{abstract}

\section{Introduction}

The research aims to determine filtration flow gradients in the dam body, analyze the reasons for their change by cross-section, estimate water filtration effect on structure elements at the example of Kattakurgan reservoir dam. To estimate the aggressiveness of filtration flow in the dam body, it is necessary to know the movement pattern of filtration water in the reservoir dam and its effect on the dam elements. The results of the analysis gain importance in providing the stability of the reservoir dam and its parts [1-6].

Filtration water in the reservoir dam body usually moves in chaotic flow. In particular, filtration flow is non-pressure flow. In non-pressure flow, filtration flow has an open surface and moves towards the side from the upper part of the dam to its lower part. The head difference is

$$
\Delta \mathrm{H}=\mathrm{H}_{1}-\mathrm{H}_{2}
$$

Filtration flow gradient $(\mathrm{J})$ is the ratio of the head difference of filtration flow in the dam body $(\Delta \mathrm{H}=\mathrm{H} 1-\mathrm{H} 2)$ to the length of the filtration path:

\footnotetext{
"Corresponding author: yangiev_asror_63@mail.ru
} 


$$
J=\frac{\Delta H}{l}
$$

Filtration flow in the dam body follows the Darcy's law. Such movement can be thoroughly observed in the base soils and in the dam body, including sands, loams, and sandy loams $[7,8]$.

Filtration flow discharge in the dam body can be determined by the following equation according to the law of the French scientist Darcy:

$$
Q=K_{f} F \frac{\Delta H}{l}=K_{\phi} F J
$$

where: $Q$ is filtration flow discharge, i.e., amount of filtrated water through soil in a unit of time, $\mathrm{m}^{3} /$ day; $K_{f}$ is filtration coefficient, i.e., the amount, expressing the ability of the dam soil pass water through itself, $\mathrm{m} / \mathrm{day} ; F$ is filtration flow zone cross-section area, $\mathrm{m}^{2} ; l$ is filtration flow path length, $\mathrm{m} ; \Delta H$ is head difference of the head race and the tail race, $\mathrm{m}$;

By dividing both sides of the equation by $(F)$, we can determine filtration velocity $v=K_{f} J$.

Thus, by Darcy's law, it is considered that the velocity (v) of filtration or water movement in the soil composing the dam body is proportionate to filtration head gradient $(J)$ and filtration coefficient. In cases when head gradient $J=\frac{\Delta H}{l}=1$, the equation $v=K J$ becomes $v=K$, i.e., filtration coefficient will be equal to filtration velocity concerning numerical value [9]. While estimating the filtration stability of the earth-fill dam and its antifiltration elements, the following conditions must be met:

$$
J_{e s t, m}=\frac{\Delta H}{t_{2}} \leq J_{c r, m}=J_{\text {dop }} \text { or } \quad J_{e s t, m} \leq \frac{1}{\mathrm{yn}_{n}} J_{c r}
$$

Were: $J_{\text {est }, m}$ is mean gradient of the dam design element; $\mathrm{\gamma}_{n}$ is dam rehabilitee coefficient (I-class-1.25; II-class-1, 2; III-class-1.15; IV-class-1.1); $J_{c r}$ is mean filtration gradient allowable for earth fill dams.

\section{Methods}

Collection of data from hydro-meteorological stations and reservoir operation. Mathematical processing of statistical data and comparison of the obtained data with field observations [10-18].

\section{Results and Discussion}

The soil of the Kattakurgan Reservoir dam consists of homogeneous local soil, and there is cover drainage in the lower partThe average gradient of filtration pressure for such reservoirs is calculated by the following formula.

$$
J_{e s t, m}=\operatorname{tg} \alpha=\frac{H}{L_{n}}(4)
$$

Here: $\alpha$ is the angle of the depression curve relative to the horizontal line; $H$ is pressure affecting the dam $\left(H=H_{1}-H_{2}\right) ; L_{n}$ is the distance between the calculated sections. 
Based on field research, gradients have been calculated between piezometers 1, 2, 3, 4, and 5, located at section № 9 (ПК 20+00) of Kattakurgan reservoir dam and the results are shown in Table 1 and Figure 2 [13, 14]. Tashkent reservoir dam cross-section is shown in Figure 1.

Table 1. Design gradients between the piezometers in the Kattakurgan reservoir dam

\begin{tabular}{|c|c|c|c|c|c|c|c|c|c|}
\hline \multirow{2}{*}{ Piezometers } & \multirow{2}{*}{ MSL } & \multicolumn{9}{|c|}{ Years } \\
\cline { 3 - 10 } & & 2010 & 2011 & 2012 & 2013 & 2014 & 2015 & 2016 & 2017 \\
\hline P15-P16 & 0.75 & 0.10 & 0.74 & 0.67 & 0.13 & 0.13 & 0.09 & 0.11 & 0.20 \\
\hline P16-P17 & 0.55 & 0.36 & 0 & 0 & 0.34 & 0.34 & 0.33 & 0.35 & 0.36 \\
\hline P17-P18 & 0.024 & 0.14 & 0.25 & 0.19 & 0.17 & 0.16 & 0.16 & 0.12 & 0.15 \\
\hline P18-P19 & 0.031 & 0.015 & 0 & 0.02 & 0.015 & 0.005 & 0.02 & 0.01 & 0.02 \\
\hline
\end{tabular}

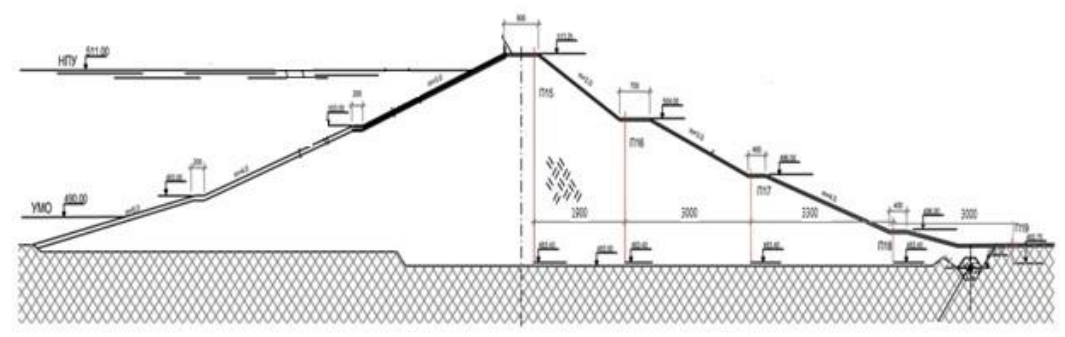

Fig. 1. Kattakurgan reservoir dam cross-section

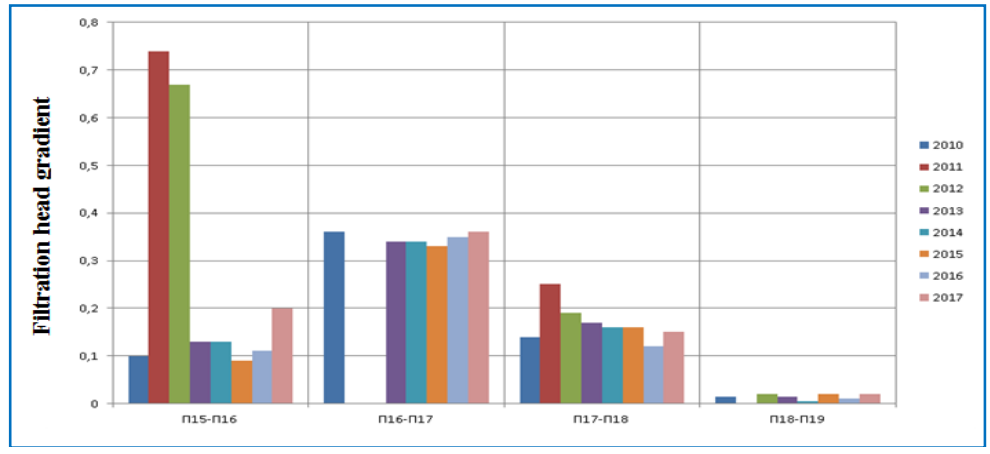

Fig. 2. Gradient change between piezometers in section (PK 20+00) of the dam

The analysis shows that filtration water movement velocity and head differences are large according to the design results, and the filtration path is short in the section between piezometers 15 and 2 . Still, in the section between piezometers 17, 18, and 19, filtration water movement velocity and head differences are low and filtration path is long. As a result, in the section between piezometers 17,18 , and 19 head gradient sharply decreases. Water stability is observed in the piezometers if the amount of gradient is very low [19-25].

On the results of the research, it is considered that the movement of soil filtration is unsteady. The unsteadiness depends on the amount of gradient between piezometers located in the dam, i.e., if the gradient is at a normal level, then the change of filtration movement will comply with the pattern, and if the amount of gradient is too low, then water level stability is observed in piezometers.

Quality change analysis was conducted for the water samples taken from the 
Kattakurgan water reservoir basin and tail race drainage to determine the state of changes mentioned above within the research and estimation of water filtration effect on the structure elements (Table 2 and figures 3 and 4).

Table 2. Chemical analysis of the quality of water, taken from Kattakurgan water reservoir basin

\begin{tabular}{|c|c|c|c|c|c|c|c|c|}
\hline \multirow{2}{*}{ Water sample point } & \multirow{2}{*}{$\mathrm{pH}$} & \multirow{2}{*}{$\begin{array}{c}\text { Hard residual, } \\
\mathrm{mg} / \mathrm{l}\end{array}$} & \multicolumn{5}{|c|}{ Amount of the basic ions dissolved in water, $\mathrm{mg} / \mathrm{l}$} \\
\cline { 4 - 9 } & & $\mathrm{HCO} 3$ & $\mathrm{Cl}^{\prime}$ & $\mathrm{SO}_{4}^{\prime \prime}$ & $\mathrm{Ca}$ & $\mathrm{Mg}$ & $\mathrm{Na}^{\prime}+\mathrm{K}-$ \\
\hline Water reservoir basin & 8.3 & 800 & 48 & 80 & 422 & 40 & 60 & 113 \\
\hline
\end{tabular}

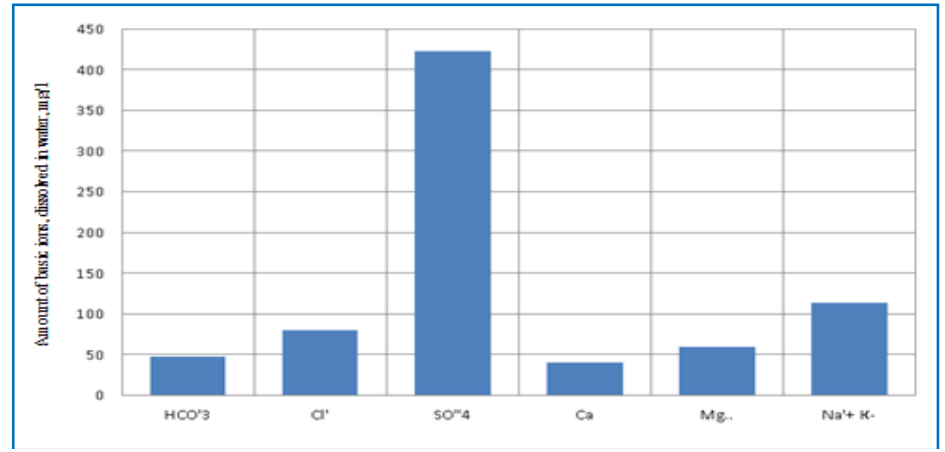

Fig. 3. Diagram of the chemical analysis of the quality of water, taken from Kattakurgan water reservoir basin

Table 3. Water aggressiveness for concrete structures in the head race of Kattakurgan water reservoir basin

\begin{tabular}{|c|c|c|c|c|c|}
\hline \multirow[b]{2}{*}{ № } & \multirow[b]{2}{*}{ Data description } & \multirow[b]{2}{*}{$\begin{array}{l}\text { Results of } \\
\text { laboratory } \\
\text { analysis }\end{array}$} & \multicolumn{2}{|c|}{ Non-pressure structure } & \multirow[b]{2}{*}{$\begin{array}{l}\text { Results of determining } \\
\text { aggressiveness } \\
\text { regarding concrete } \\
\text { structures }\end{array}$} \\
\hline & & & $\begin{array}{l}\text { Portland } \\
\text { cement } \\
\text { original and } \\
\text { sulfate } \\
\text { resistant } \\
\end{array}$ & $\begin{array}{c}\text { Pupallan and } \\
\text { Portland cement } \\
\text { with slag original } \\
\text { and sulfate } \\
\text { resistant }\end{array}$ & \\
\hline 1 & 2 & 3 & 4 & 5 & 6 \\
\hline 1 & Type of structure & Nonpressure & & & \\
\hline 2 & $\begin{array}{c}\text { Size of } \\
\text { structure, } \mathrm{m}\end{array}$ & Above 2.5 & & & \\
\hline 3 & $\mathrm{Kf}, \mathrm{m} /$ day & $0.1<\mathrm{Kf}<10$ & & & \\
\hline 4 & $\mathrm{Ca}^{2+}, \mathrm{mg} / \mathrm{l}$ & 48.8 & & & \\
\hline 5 & $\mathrm{pH}$ & 8.3 & 5.2 & 5.5 & $\begin{array}{l}\text { Water has no general } \\
\text { acidic aggressiveness }\end{array}$ \\
\hline 6 & $\mathrm{HCO}_{3}^{-}, \mathrm{mg} / 1$ & 0.7872 & 0.4 & not regulated & $\begin{array}{c}\text { Water has no alkaline } \\
\text { aggressiveness }\end{array}$ \\
\hline 7 & Carbon acid $\mathrm{CO}_{2}, \mathrm{mg} / \mathrm{l}$ & not defined & & & $\begin{array}{l}\text { Water has no carbon } \\
\text { acid aggressiveness }\end{array}$ \\
\hline 8 & Chloride, $\mathrm{Cl}^{-}, \mathrm{mg}$ & 80 & & & \\
\hline 9 & SulphateSO ${ }_{4}{ }^{2-}, \mathrm{mg} / \mathrm{l}$ & 422 & $422>350$ & $422>350$ & $\begin{array}{c}\text { Has sulphate } \\
\text { aggressiveness for } \\
\text { ordinary cement } \\
\text { structures }\end{array}$ \\
\hline 10 & $\mathrm{Mg}^{2+}, \mathrm{mg} / \mathrm{l}$ & 60 & $60<1000$ & $60<1000$ & $\begin{array}{c}\text { water has no } \\
\text { magnesium } \\
\text { aggressiveness }\end{array}$ \\
\hline
\end{tabular}


In estimating the filtration water aggressiveness stability of the dam elements in the reservoir, it is necessary to consider the soil filtration coefficient. The aggressive effect of water on the elements located in soils, where the filtration coefficient is large, can also be high. Based on this, water aggressiveness has also been estimated for concrete structures in the head race of the Kattakurgan water reservoir basin (Table 3). Also, the aggressiveness of water has been specified for concrete structures and piezometers located in the body of the dam (Table 4) [26-31].

Table 4. Piezometers and water quality from downstream drainage

\begin{tabular}{|c|c|c|c|c|c|c|c|c|}
\hline $\begin{array}{c}\text { Water } \\
\text { sample } \\
\text { taken point }\end{array}$ & $\mathrm{pH}$ & $\begin{array}{c}\text { Dry } \\
\text { residue, } \\
\mathrm{mg} / \mathrm{l}\end{array}$ & \multicolumn{5}{|c|}{ Amount of basic ions dissolved in water, $\mathrm{mg} / 1$} \\
\cline { 4 - 9 } & & $\mathrm{HCO}_{3}^{\prime}$ & $\mathrm{Cl}^{\prime}$ & $\mathrm{SO}_{4}^{\prime}$ & $\mathrm{Ca} .$. & $\mathrm{Mg} .$. & $\mathrm{Na}^{\prime}+\mathrm{K}-$ \\
\hline $\begin{array}{c}\text { piezometer } \\
15\end{array}$ & 6.2 & 4510 & 36 & 40 & 2989 & 560 & 276 & 303 \\
\hline $\begin{array}{c}\text { piezometer } \\
16\end{array}$ & 8.6 & 4330 & 24 & 40 & 2929 & 260 & 288 & 593 \\
\hline $\begin{array}{c}\text { piezometer } \\
17\end{array}$ & 6.8 & 6030 & 98 & $\begin{array}{c}32 \\
0\end{array}$ & 3858 & 120 & 288 & 1406 \\
\hline $\begin{array}{c}\text { piezometer } \\
18\end{array}$ & 8.1 & 5890 & 305 & $\begin{array}{c}30 \\
0\end{array}$ & 3741 & 40 & 648 & 827 \\
\hline $\begin{array}{c}\text { piezometer } \\
19\end{array}$ & 8.1 & 2260 & 84 & $\begin{array}{c}10 \\
0\end{array}$ & 1478 & 80 & 252 & 235 \\
\hline \begin{tabular}{c} 
Drainage \\
\hline
\end{tabular} & 7.9 & 2390 & 146 & $\begin{array}{c}10 \\
0\end{array}$ & 1555 & 260 & 168 & 247 \\
\hline
\end{tabular}

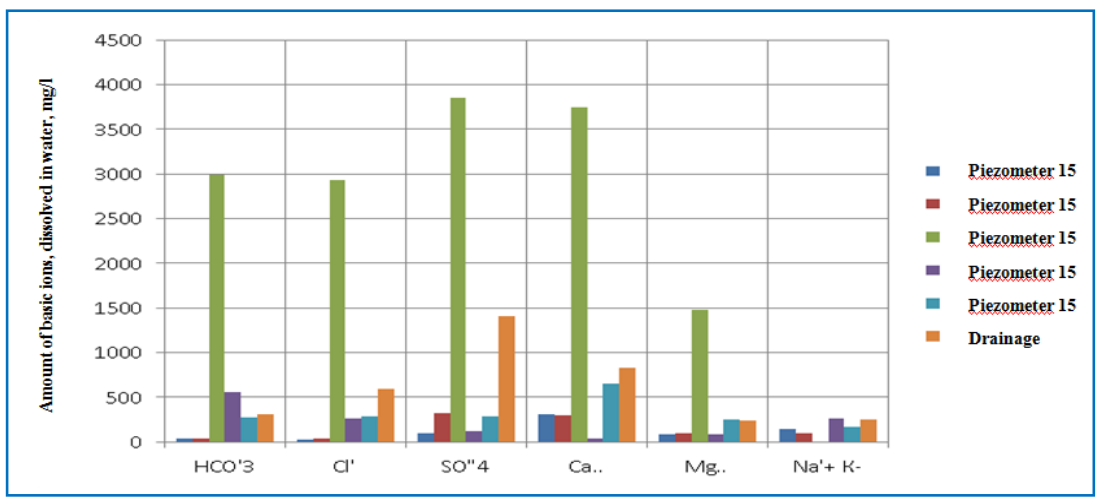

Fig. 4. Diagram of change in water quality obtained from piezometers and tail race drainage. 
Table 5. Aggressive effect on concrete structures and piezometers of filtration water, located in the body of Kattakurgan water reservoir dam

\begin{tabular}{|c|c|c|c|c|c|}
\hline \multirow[b]{2}{*}{ № } & \multirow[b]{2}{*}{$\begin{array}{c}\text { Data } \\
\text { description }\end{array}$} & \multirow[b]{2}{*}{$\begin{array}{l}\text { Results of } \\
\text { laboratory } \\
\text { analysis }\end{array}$} & \multicolumn{2}{|c|}{ No pressure structure } & \multirow[b]{2}{*}{$\begin{array}{l}\text { Results of determining } \\
\text { aggressiveness regarding } \\
\text { concrete structures }\end{array}$} \\
\hline & & & $\begin{array}{l}\text { Portland } \\
\text { cement } \\
\text { original and } \\
\text { sulfate } \\
\text { resistant }\end{array}$ & $\begin{array}{c}\text { Pupallan and } \\
\text { Portland cement with } \\
\text { slag original and } \\
\text { sulfate resistant }\end{array}$ & \\
\hline 1 & 2 & 3 & 4 & 5 & 6 \\
\hline 1 & $\begin{array}{c}\text { Typeof } \\
\text { structure }\end{array}$ & Non pressure & & & \\
\hline 2 & $\begin{array}{c}\text { Size of } \\
\text { structure, } \mathrm{m}\end{array}$ & Above 2.5 & & & \\
\hline 3 & Kf, m/day & $0.1<K_{f}<10$ & & & \\
\hline 4 & $\mathrm{Ca} 2+, \mathrm{mg} / \mathrm{l}$ & 560 & & & \\
\hline 5 & $\mathrm{pH}$ & 8.3 & 5.2 & 5.5 & $\begin{array}{c}\text { Water has no general acidic } \\
\text { aggressiveness }\end{array}$ \\
\hline 6 & $\begin{array}{l}\mathrm{HCO}_{3}, \\
\mathrm{mg} \cdot / 1\end{array}$ & $\begin{array}{c}\text { from } \\
0.4 \text { to } 5.0\end{array}$ & 0.4 & Not standardized & $\begin{array}{l}\text { At the point where the } 16 \\
\text { piezometers are located, } \\
\text { there is alkaline } \\
\text { aggressiveness of filtration } \\
\text { water }\end{array}$ \\
\hline 7 & $\begin{array}{c}\text { Carbon Acid } \\
\mathrm{CO}_{2}, \mathrm{mg} / \mathrm{l}\end{array}$ & not defined & & & $\begin{array}{l}\text { Water has no carbon acid } \\
\text { aggressiveness }\end{array}$ \\
\hline 8 & $\begin{array}{c}\text { Chloride } \mathrm{Cl}^{-}, \\
\mathrm{mg}\end{array}$ & from 40 to 320 & $320<1000$ & $320<1000$ & $\begin{array}{c}\text { Accelerates corrosion of } \\
\text { metal structures }\end{array}$ \\
\hline 9 & $\begin{array}{l}\text { Sulphate } \\
\text { SO42-, mg/l }\end{array}$ & $\begin{array}{l}\text { from } 1478 \text { to } \\
\quad 3858\end{array}$ & $3858>250$ & $3858>250$ & $\begin{array}{l}\text { Has sulfate aggressiveness } \\
\text { for ordinary cement } \\
\text { structures and metal } \\
\text { structures }\end{array}$ \\
\hline 10 & $\mathrm{Mg}^{2+}, \mathrm{mg} / \mathrm{l}$ & 648 & $648<1000$ & $648<1000$ & $\begin{array}{c}\text { water has no magnesium } \\
\text { aggressiveness }\end{array}$ \\
\hline
\end{tabular}

\section{Conclusions}

Filtration flow in the body of the Kattakurgan water reservoir dam is sulfate aggressive about concrete and metal structures; it accelerates the corrosion of piezometers in the dam. It requires taking measures to process the concrete surfaces and joints on the headrace of the Kattakurgan water reservoir dam with hydroisolation materials and providing good operation of drainage in the tailrace of the dam. The sensitivity of piezometers in the water reservoir dam must be checked; during the process of checking, the sensibility piezometers must be filled with water and then emptied, thus providing the process of water replacement in them. As a result, filtration flow water aggressiveness will decrease concerning piezometers. 


\section{References}

1. Bakiev M.R., Tursunov T.N., Kaveshnikov N.T. Operation of hydraulic structures. Tashkent, (2008)

2. Law of the Republic of Uzbekistan «On the safety of hydraulic structures».

3. Malik L.K., Extreme situations, related with hydraulic structure. Hydraulic construction. № 12. pp.1-16, (2009)

4. Asarin A.E., Semenkov V.M. Design flood and dam safety. Hydraulic construction. № 8. pp.55-57, (1992)

5. Muhammedov A.M. Operation of low-pressure hydro systems in rivers, transporting sediment (at the example of Central Asia). Science. p.237, Tashkent, (1976)

6. Designer is manual. Hydraulic structures. Revised by Nedriga V.P.(1983)

7. Mirihulava S.E. Reliability of hydro-melioration structures. Moscow. (1974)

8. Goldberg V.M. Relationship between underground water pollution and natural environment. Hydrometeo publ. house, p.248, Leningrad, (1987)

9. Yangiev A.A., Gapparov F.A., Adjimuratov D.S. Filtration process in earth fill dam body and its chemical effect on piezometers. E3S Web of Conferences 97, 04041 FORM-(2019)

10. Yangiev A.A., Ashrabov A., Muratov O.A. Life prediction for spillway facility sidewall. E3S Web of Conferences 97, 04041, (2019)

11. Yangiev A.A., Bakiev M.R., Muratov O.A., Choriev J.M., Djabbarova S. Service life of hydraulic structure reinforced concrete elements according to protective layer carbonization criteria Journal of Physics: Conference Series 1425(1).

12. Joldassov S.K., Sarbassova G.A., Bekmuratov M.M., Zholamanov N.Z., Yangiev A.A. New structures of sediment exclusion works. News of the National Academy of Sciences of the Republic of Kazakhstan, Series of Geology and Technical Sciences 6(438). pp.184-189, (2019)

13. Yangiev A.A. Perfection of designs, settlement substantiation and operational reliability of vertical mine spillways of highly pressure head hydro knots. p.25, Tashkent, (2016)

14. Fayzullaev D.R., Hydromechanical models of movement. p.285, Tashkent, (1985)

15. VolshanikV.V., Zuykova A.L., Mordasov A.P. Theswirling flowsin hydraulic engineering structures. Energy autom. publ. house. p.230, Moscow, (1990)

16. Zuykova A.L.,Volshanik V.V. Analytical research of structure of swirling flows of a viscous incompressible fluid in a cylindrical pipe. p.155, Moscow, (2001)

17. Isakov Sh.R., Ruzmetov M.I., Khamidov A.A. Axsymmetrical problem on speed and concentration distribution in the swirling flow of a dispersed mixture. The international conference «Modern problems of mechanics» pp.36-42, Saint Petersburg, (2009)

18. Bazarov D., Vatin N., Obidov B., and Vokhidov O. Hydrodynamic effects of the flow on the slab of the stand in the presence of cavitation. IOP Conf. Ser. Mater. Sci. Eng. 1030, 012110 (2021).

19. Bazarov D., Markova I., Norkulov B. and Vokhidov O. Hydraulic aspects of the layout of head structures during water intake from lowland rivers. IOP Conf. Ser. Mater. Sci. Eng. 1015, 012041 (2021)

20. Bazarov D., Markova I., Sultanov S. and Kattakulov F. Dynamics of the hydraulic and alluvial regime of the lower reaches of the Amudarya after the commissioning of the Takhiatash and Tuyamuyun hydrosystems. IOP Conf. Ser. Mater. Sci. Eng. 1030, 012110 (2021).

21. Bazarov D. and Vokhidov O. Extinguishing Excess Flow Energy in Spillway Structures. In book: Proceedings of EECE 2020, LNCE 150, pp. 535-545, (2021) 
DOI: 10.1007/978-3-030-72404-7_52

22. Bazarov D., Markova I., Norkulov B., Isabaev K., Sapaeva M. Operational efficiency of water damless intake. IOP Conf. Ser. Mater. Sci. Eng. 869(7), 072051, (2020)

23. Jivotovskiy B.A. Hydraulics of the twirled streams and their application in hydraulic engineering. p.325, Moscow, (1986)

24. Yangiev A.A., Eshev S.S., Panjiev S., Rakhimov A, Calculation of sediment flow in channels taking into account passing and counter wind waves IOP Conference Series: Materials Science and Engineering 883, (2020)

25. Khanov N.V. Vertical spillways with inclined mine and tangential for swirled. p.169, (1994)

26. Gur'ev,A.P., Kozlov D.V., Khanov N.V., Abidov M.M., Safonova N.A. Alternative Solutions for the Energy Dissipation of Idle Discharges at the Rogun HPP, Power Technology and Engineering, 54(1), pp. 7-12, (2020)

27. Baranov E.V., Gur'yev A.P., Khanov N.V. Recommendations for Hydraulic Calculations of Anti-Erosion Lining with the Use of Spatial Geogrid with Coarse Fragmental Soil, Power Technology and Engineering, 53(5), pp. 553-556, (2020)

28. Khanov N.V., Martynov D.Y., Novichenko A.I., Lagutina N.V., Rodionova S.M. Outlook and Special Properties of Earth Anchors and Screw Piles in Burial of Modular Protection Dikes in Nonrocky Ground, Power Technology and Engineering, 52(4), pp. 405-412, (2018)

29. Kurbanov S.O., Khanov N.V. To calculation of the critical depths of the canals with polygonal profile (PP), Gidrotekhnicheskoe Stroitel'stvo, (3), pp. 42-44, (2004)

30. Kurbanov S.O., Khanov N.V. To hydraulic calculation of the most favorable sections of the power diversion canals (PDC) of a polygonal profile, Gidrotekhnicheskoe Stroitel'stvo, (7), pp. 40-43, (2003)

31. Khanov N.V. Hydraulic characteristics of chamber-free tangential vortex flow generators, Hydrotechnical Construction, 33(2), pp. 99-103, (1999) 